\title{
THE EFFECTIVENESS OF THE E-LEARNING APPLICATIONS: ASSESSMENT OF THE SERVICE QUALITY USING BINOMINAL LOGISTIC REGRESSION
}

\section{Peter Lengyel $^{1 \bowtie}$, Miklós Herdon², János Pancsira ${ }^{3}$, Gergely Ráthonyi ${ }^{3}$, István Füzesi²}

${ }^{1 \bowtie}$ Department of Business Informatics, Faculty of Economics and Business, University of Debrecen, Böszörményi út 138., Hungary, Debrecen, 4032, Hungary, +36 52 508-441, lengyel.peter@econ.unideb.hu

${ }^{2}$ Department of Business Informatics, Faculty of Economics and Business, University of Debrecen, Hungary

${ }^{3}$ Department of Agricultural Informatics, Faculty of Economics and Business, University of Debrecen, Hungary

\section{Highlights}

- $\quad$ Our research objectives include the quality of e-Learning establishment of our institution

- We used statistic methods to examine the quality evaluation of the e-Learning usage

- It is more effective and better to operate the e-Learning system under organized circumstances

\section{Abstract}

The success and the efficiency of e-Learning should be measured by a reliable method in order to use it effectively. Although, there are several studies about the success of e-Learning systems, only a few of them deal with the measurement of this success within the institutions.

We made a questionnaire to evaluate the e-Learning application. The aim was to develop such questionnaire which is suitable to evaluate e-Learning quality. The basis of the e-Learning quality questions was a multi-dimensional model for assessing e-learning systems success (ELSS).

The aim of the questionnaire were to compare the opinions of the students and the teachers and also to evaluate the Faculty of Economics and Business (FEB) of the University of Debrecen and the Corvinus University of Budapest (CUB) regarding the application of e-Learning. The role of the questionnaire for quality development is to give guidance for the FEB in implementing and using e-Learning. E-Learning in the CUB is applied under certain organized institutional circumstances. The e-Learning application of CUB works with an organization defined extended several faculties of the University, which can be a good example for FEB.

We have used factor analysis and binominal logistic regression. We have examined whether the background variables manipulating the variables are possible to be developed on the basis of the answers. We used factor analysis to demonstrate this since it contracts the coherent factors into one common factor. Finally we used logistic regression to determine the importance of a given factor for the users of both faculties.

\section{Keywords}

E-learning, higher education, binomial logistic regression

Lengyel P., Herdon M., Pancsira J., Ráthonyi G., Füzesi I. (2017) “The Effectiveness of The E-learning Applications: Assessment of The Service Quality Using Binominal Logistic Regression”, Journal on Efficiency and Responsibility in Education and Science, Vol. 10, No. 2, pp. 51-57, online ISSN 1803-1617, printed ISSN 2336-2375, doi: 10.7160/eriesj.2017.100203.

\section{Introduction}

The number of educational institutions, companies and other users who applying e-Learning systems has grown significantly in the last decade, therefore they have become as important means and resources as other information systems of the institutions (Szilágyi, 2012). However, there are several conditions and components to use these systems in the educational institutions successfully. Important issues for example what kind of system is chosen, how it is implemented and introduced. The availability of the system and services are also important for the users (teachers, students) (Lengyel et al, 2016).

Probably the most significant question is how teachers and students can profit from the system. What is the advantage of using it? How does it help the process of teaching and learning to become more effective and transparent? Does it support the management of institutional education? If it does so, what extent? Naturally, the organizational and economical aspects of the usage of e-Learning systems are also important. The application of the e-Learning systems is gradually becoming more essential for those institutions, organizations and companies have distance learning and also useful for the improvement of human resources.

The Learning Management System (LMS) is often used with a virtual learning environment (VLE) interchangeably. A VLE refers to an operating system and specialized learning management software that allows students and the instructor to plan, organize, monitor, coordinate, and control the learning activities to facilitate the learning process and to optimize the desired learning outcomes.

The DeLone and McLean (D\&M) model is one of the widely recognized information system (IS) success models based on a systematic review of 180 studies with over 100 measures. The DM model theorized that system quality and information quality singularly and jointly affect both use and user satisfaction, which in turn, are direct antecedents of system effectiveness (DeLone and McLean, 1992). To extend the DM model into the e-learning area, a number of studies empirically tested the D\&M model of information systems success model in a university e-learning context using structural equation modeling. Eom and others (Eom et al, 2012) presented empirical test of the D\&M model of IS success in a university e-learning context, which is strictly involuntary use. Their study reached several useful conclusions. Perceived system quality and perceived information quality are very strong (high path coefficient) predictor of user satisfaction. Perceived user satisfaction is a very strong predictor of individual impact. Perceived system quality is an insignificant predictor of system use or relatively weak predictor of system use. The direct influence of system use on user satisfaction is weak even though it is statistically significant. In order for e-learning students to be successful, they must be provided with e-learning system that provides information they need and user-friendly. 
Although system quality has not directly contributed to predict individual impact, its impact is indirect. System quality and information quality have positive effects on user satisfaction. Information quality has also positive effects on system use, which in turn positively contributes to user satisfaction. Therefore, all the antecedent variables are positively affecting e-learning outcomes either indirectly or directly. System quality and information quality are necessary conditions for e-learning success and students' satisfaction with LMS, but not sufficient conditions (Eom, 2015).

Our research objectives include the quality of e-Learning establishment and the support of our institution. Accordingly, tasks were set for the examination of e-Learning opportunities for quality improvement in education, improvements in this regard, proposals and recommendations for application development. The course structure recommended for the application of e-Learning for institutional quality improvement together with other functions reachable as a module of the system, can ensure an integrated and comprehensive e-Learning quality service. The strategy and implementation of quality improvement is only possible by providing qualified human resources. The basic objective of the introduced LMS (Learning Management System) is to improve the quality of education, which is one way where the students and instructors receive ongoing feedback about their experiences with the system (Wang, Wang and Shee, 2007). Corresponding objective is to compile a questionnaire, which was a result of useful information about the students and teachers e-Learning system and application views (Lengyel and Herdon, 2012).

The aim of the questionnaires were to compare the opinions of the students and the teachers and also to evaluate the Faculty of Economics and Business (FEB) of the University of Debrecen and the Corvinus University of Budapest (CUB) regarding the e-Learning applications. The role of the questionnaire for quality development is to give guidance for the FEB in the application of e-Learning. E-Learning in the CUB is applied under certain organized institutional circumstances. The e-Learning application of CUB works with an organization defined extended several faculties of the University, which can be a good example for our faculty.

The following hypotheses was defined: The quality development of e-Learning should be ensured under organized circumstances.

\section{Matherials and methods}

\section{Questionnaire survey}

There is an on-line way of response, which is a quantitative online CAWI (Computer Assisted Web Interviews) survey over the Internet. Usually rapid market surveys are made by this method. Our questionnaire was accessible through Limesurvey system (Figure 1), which is a free and open source on-line survey application written in PHP based on a MySQL database. As a web server-based software it enables users using a web interface to develop and publish on-line surveys, collect responses, create statistics, and export the resulting data to other applications (Bocarnea, Reynolds and Baker, 2012).

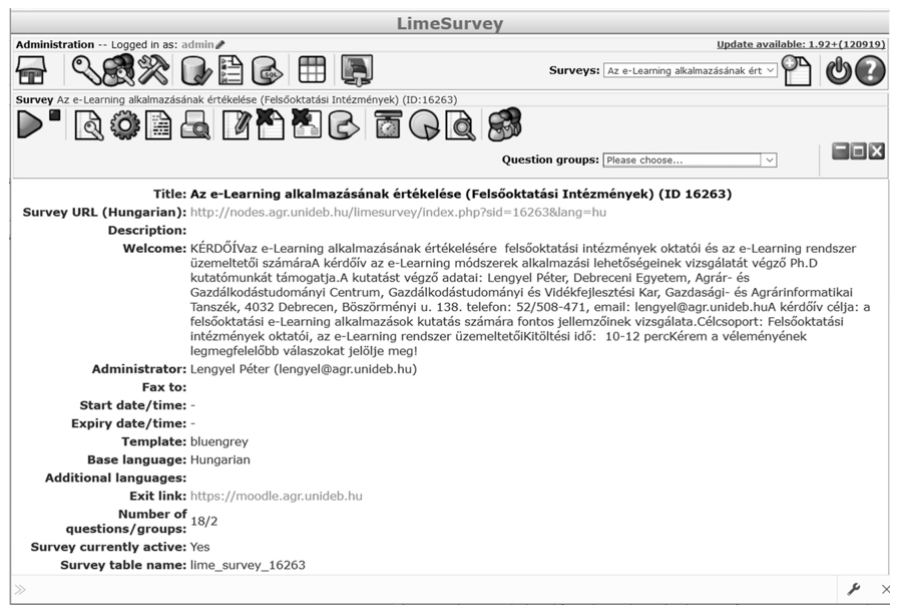

Figure 1: Administration interface of Limesurvey system (source: http://nodes.agr.unideb.hu/limesurvey/index. php?sid=16263\&lang=hu, 2016)

The research survey designed from the predetermined group of users to get answers to important research questions. The SPSS (Statistical Package for the Social Sciences) program was used to evaluate the questionnaires. The questionnaire responses from LimeSurvey were exported to the files that we imported into SPSS.

\section{The applied statistical methods}

A statistically significant t-test result is one in which a difference between two groups is unlikely to have occurred because the sample happened to be atypical. Statistical significance is determined by the size of the difference between the group averages, the sample size, and the standard deviations of the groups. For practical purposes statistical significance suggests that the two larger populations from which we sample are "actually" different.

We used factor analysis and binominal logistic regression too. We examined whether the background variables manipulating the variables are possible to be developed on the basis of the answers. We used factor analysis to demonstrate this since it contracts the coherent factors into one common factor. Factor analysis is used to compress data and explore data structure (Szakály et al, 2014, Balogh et al, 2015). This method contracts the basic variables into so called factor variables which cannot be directly observed. In most cases, factor analysis is used foremost in order to filter out multicollinearity (Field, 2009). Logistic regression quantifies the probability of occurrence of the category of a doubtful, category like dependent variable under the condition of the known outcomes of other explanatory variables. Logistic regression is a non-linear classification method that does not suppose the continuity of explanatory variables neither the normality of multivariables. The decisionmaker can construct a decision-making rule relying on the hypothetical probability value in order to classify the given observation unit into a predetermined result like category ( $\mathrm{Gal}$ et al, 2013). If the number of the dependent variables' outcome is two, then the method is called a binomial logistic regression.

\section{The applied model}

The success and the efficiency of e-Learning should be measured by a reliable method in order to use it effectively. Although, there are several studies about the success of e-Learning systems, only a few of them is about the measurement of this success within the institutions (Karima and Mostafa, 2016, Li, Fu and Duan, 2013, Silambannan and Srinath, 2013). It is a study by Wang, Wang and Shee (2007), in which they measured the success of 
the e-Learning systems with e-Learning System Success (ELSS) model based on DeLone and McLean (2003) Information System Success Model.

\section{Results}

The aim was to develop such questionnaires which are suitable both for the evaluation of the e-Learning's quality. The basis of the e-Learning's quality questions was the ELSS model. The questions of the students and the lecturers were the same.

The groups of questions were the following:

- $\quad$ System quality (1-7)

- Information quality (8-12)

- $\quad$ Service quality (13-17)

- Benefits of the e-Learning system (18-24)

- Conclusions (25-27)

The questionnaire involving 27 questions is shown in the Appendix. There were 273 students and 50 lecturers from the CUB and 288 students and 46 teachers from the UD FEB who properly filled out the questionnaires. We examined the answers about the e-Learning quality in this research on the basis of two criterion (student-teacher, CUB - FEB). The basis of the answers' comparability was that both institutions applied the Moodle frame system. We tried to find out what extent they exploit the facilities of the system.

The 27 questions could be answered in a scale of 10. Figure 2 represents a diagram that indicates the means of the answers of the two institutions' students and teachers.

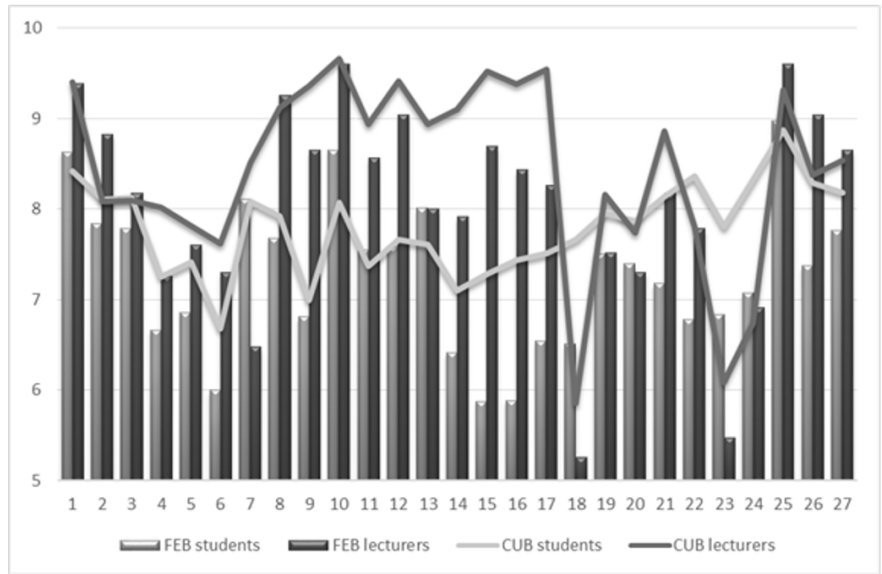

Figure 2: Comparison of the students and teachers responses at FEB and CUB (source: own calculation)

We can see on Figure 2 that generally, according to the e-Learning users of the CUB, the quality of the e-Learning application is better. The answers are demonstrating significant differences based on the results of t-tests, therefore we find significant differences in the answers.

The significant differences in the lecturers' answers is illustrated by Table 1 and Table 2 naming the difference indicator issues. All results were higher at Benchmark excepting for the question 2 and 26. Before t-test we calculated descriptive statistics with SPSS (Appendix 2). Within the results for t-test for Equality of Means, the results were displayed into Equal Variances assumed (E.v.a.) and not assumed (E.v. not a.).

\begin{tabular}{|c|c|c|c|c|c|c|c|c|}
\hline \multirow{2}{*}{\multicolumn{2}{|c|}{ question }} & \multicolumn{2}{|c|}{$\begin{array}{l}\text { Levene's Test } \\
\text { for Equality of } \\
\text { Variances }\end{array}$} & \multicolumn{5}{|c|}{ t-test for Equality of Means } \\
\hline & & \multirow{2}{*}{$\begin{array}{c}\text { F } \\
2.704\end{array}$} & \multirow{2}{*}{$\begin{array}{l}\text { Sig. } \\
0.103\end{array}$} & \multirow{2}{*}{$\begin{array}{c}\mathrm{t} \\
3.341\end{array}$} & \multirow{2}{*}{$\begin{array}{l}\text { df } \\
94\end{array}$} & \multirow{2}{*}{$\begin{array}{c}\begin{array}{c}\text { Sig. } \\
(2 \text {-tai- } \\
\text { led) }\end{array} \\
0.001\end{array}$} & \multirow{2}{*}{$\begin{array}{l}\begin{array}{l}\text { Mean } \\
\text { Diffe- } \\
\text { rence }\end{array} \\
0.7461 \\
\end{array}$} & \multirow{2}{*}{$\begin{array}{r}\text { Std. Error } \\
\text { Difference }\end{array}$} \\
\hline & E.v.a. & & & & & & & \\
\hline 2. & \begin{tabular}{|l|} 
E.v. \\
not a.
\end{tabular} & & & 3.380 & 90.657 & 0.001 & 0.7461 & 0.2207 \\
\hline \multirow[b]{2}{*}{7.} & E.v.a. & 21.558 & 0.000 & -5.024 & 94 & 0.000 & -2.0417 & 0.4064 \\
\hline & \begin{tabular}{|l|} 
E.v. \\
not a.
\end{tabular} & & & -4.895 & 64.022 & 0.000 & -2.0417 & 0.4171 \\
\hline \multirow[b]{2}{*}{9.} & E.v.a. & 34.140 & 0.000 & -2.215 & 94 & 0.029 & -0.7078 & 0.3195 \\
\hline & \begin{tabular}{|l|} 
E.v. \\
not a.
\end{tabular} & & & -2.141 & 53.624 & 0.037 & -0.7078 & 0.3306 \\
\hline \multirow[b]{2}{*}{13.} & E.v.a. & 10.075 & 0.002 & -2.625 & 94 & 0.010 & -0.9400 & 0.3581 \\
\hline & \begin{tabular}{|l|} 
E.v. \\
not a.
\end{tabular} & & & -2.539 & 54.687 & 0.014 & -0.9400 & 0.3702 \\
\hline \multirow[b]{2}{*}{14.} & E.v.a. & 8.619 & 0.004 & -4.479 & 94 & 0.000 & -1.1870 & 0.2650 \\
\hline & \begin{tabular}{|l|} 
E.v. \\
not a.
\end{tabular} & & & -4.342 & 57.460 & 0.000 & -1.1870 & 0.2733 \\
\hline \multirow[b]{2}{*}{15.} & E.v.a. & 47.302 & 0.000 & -3.510 & 94 & 0.001 & -0.8243 & 0.2349 \\
\hline & \begin{tabular}{|l|} 
E.v. \\
not a. \\
\end{tabular} & & & -3.413 & 61.405 & 0.001 & -0.8243 & 0.2415 \\
\hline \multirow[b]{2}{*}{16.} & E.v.a. & 18.063 & 0.000 & -4.011 & 94 & 0.000 & -0.9452 & 0.2357 \\
\hline & $\begin{array}{l}\text { E.v. } \\
\text { not a. }\end{array}$ & & & -3.908 & 64.075 & 0.000 & -0.9452 & 0.2419 \\
\hline \multirow[b]{2}{*}{17.} & E.v.a. & 56.573 & 0.000 & -3.957 & 94 & 0.000 & -1.2791 & 0.3232 \\
\hline & \begin{tabular}{|l} 
E.v. \\
not a.
\end{tabular} & & & -3.817 & 51.447 & 0.000 & -1.2791 & 0.3351 \\
\hline \multirow[b]{2}{*}{26.} & E.v.a. & 2.879 & 0.093 & 2.927 & 94 & 0.004 & 0.6635 & 0.2267 \\
\hline & $\begin{array}{l}\text { E.v. } \\
\text { not a. }\end{array}$ & & & 2.974 & 86.273 & 0.004 & 0.6635 & 0.2231 \\
\hline
\end{tabular}

Table 1: Significant differences in teachers' answers (source: own calculation)

Regarding the result it can be said that the e-Learning application of the CUB is more successful than the FEB according to the students' and the lecturers' evaluation. It is also obvious that the quality of the system's operation of the CUB is higher than the FEB. This result supports our hypothesis according to which the FEB can evolve in the quality of e-Learning application by ensuring the institutional frames for the system.

After that we examined whether background variables influencing the variables are possible to be formed. We analyzed the whole database used factor analysis to demonstrate this contracts the coherent factors into one common factor. We examined the variables on the basis of the Kaiser-Meyer-Olkin (KMO) criteria to determine whether they are suitable for factor analysis (Várallyai, Botos and Péntek, 2015). The value of the $\mathrm{KMO}$ is 0.886 (Table 3 ), which means that the variables are suitable for factor analysis.

The table also indicates the null hypothesis of the Bartlett test, which means that there is no correlation between the basic variables because the level of significance (Sig.) is smaller than 0.05. Consequently the basic condition of the factor analysis, according to which the variables must correlate is fulfilled (Sajtos and Mitev, 2007). 


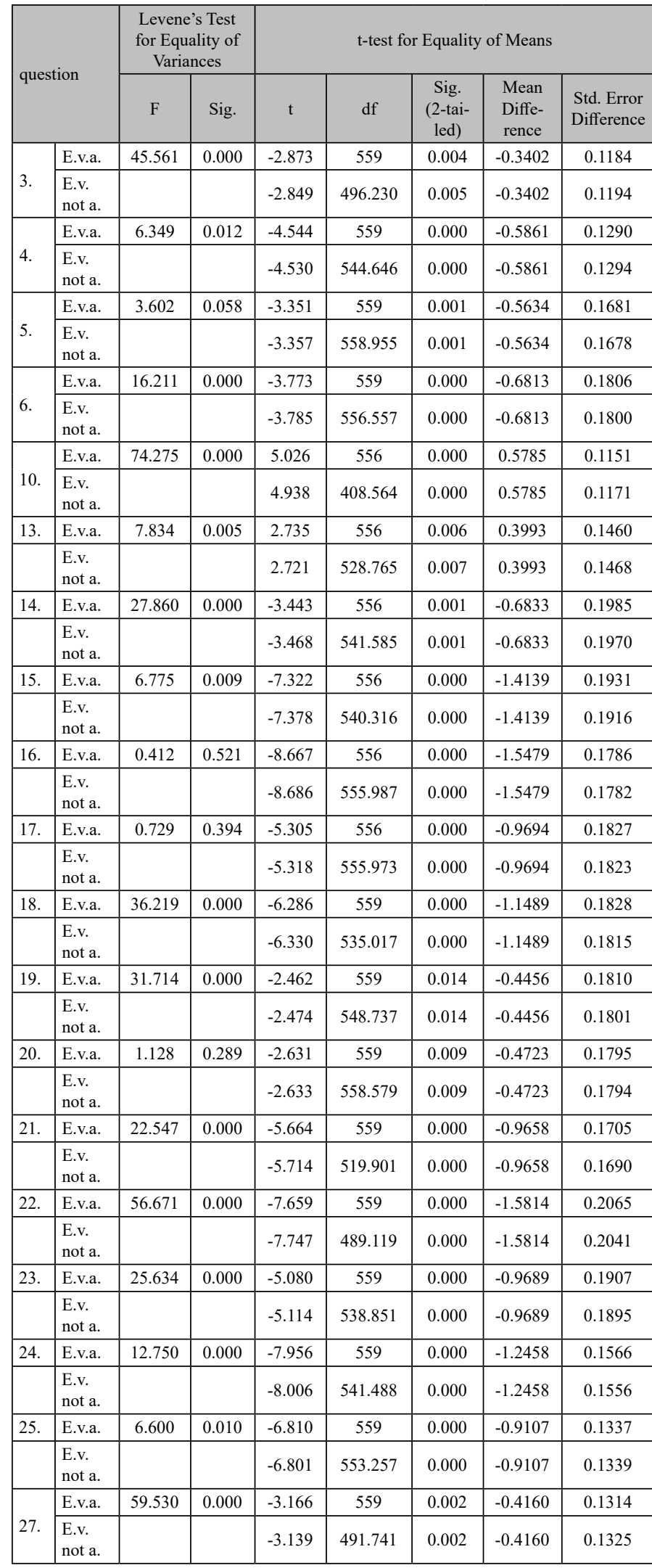

Table 2: Significant differences in students' answers (source: own calculation)

\begin{tabular}{|l|l|r|}
\hline Kaiser-Meyer-Olkin Measure of Sampling Adequacy. & 0.886 \\
\hline \multirow{3}{*}{ Bartlett's Test of Sphericity } & Approx. Chi-Square & 17114.773 \\
\cline { 2 - 3 } & df & 351 \\
\cline { 2 - 3 } & Sig. & 0.000 \\
\hline
\end{tabular}

Table 3: The results of KMO and Bartlett test (source: own calculation)

We used two methods to determine the number of the factors. One of them is the percentage of variance, which determines the number of the factors on the basis of the cumulated percentage of the variance, which means that it is necessary to establish such number of the factors which makes it possible to reach a cumulated minimal level of variance. The Table 4 indicates the variance explained by the factors.

\begin{tabular}{|l|c|c|c|c|c|c|c|c|c|}
\hline \multirow{2}{*}{$\begin{array}{l}\text { Fac- } \\
\text { tor }\end{array}$} & \multicolumn{3}{|c|}{ Initial Eigenvalues } & \multicolumn{3}{c|}{$\begin{array}{c}\text { Extraction Sums of } \\
\text { Squared Loadings }\end{array}$} & \multicolumn{3}{|c|}{$\begin{array}{c}\text { Rotation Sums of Squa- } \\
\text { red Loadings }\end{array}$} \\
\cline { 2 - 11 } & Total & $\begin{array}{c}\% \text { of } \\
\text { Vari- } \\
\text { ance }\end{array}$ & $\begin{array}{c}\text { Cumu- } \\
\text { lative } \\
\%\end{array}$ & Total & $\begin{array}{c}\% \text { of } \\
\text { Vari- } \\
\text { ance }\end{array}$ & $\begin{array}{c}\text { Cumu- } \\
\text { lative } \\
\%\end{array}$ & Total & $\begin{array}{c}\% \text { of } \\
\text { Vari- } \\
\text { ance }\end{array}$ & $\begin{array}{c}\text { Cumu- } \\
\text { lative } \\
\%\end{array}$ \\
\hline 1 & 11.526 & 42.690 & 42.690 & 11.192 & 41.452 & 41.452 & 6.140 & 22.740 & 22.740 \\
\hline 2 & 3.621 & 13.410 & 56.100 & 3.317 & 12.285 & 53.737 & 5.893 & 21.825 & 44.565 \\
\hline 3 & 1.944 & 7.201 & 63.301 & 1.566 & 5.800 & 59.538 & 3.105 & 11.501 & 56.066 \\
\hline 4 & 1.500 & 5.554 & 68.855 & 1.264 & 4.681 & 64.219 & 2.201 & 8.153 & 64.219 \\
\hline 5 & 1.090 & 4.037 & 72.892 & & & & & & \\
\hline 6 & 0.953 & 3.530 & 76.423 & & & & & & \\
\hline
\end{tabular}

Table 4: Choice factors in the method variance (source: own calculation)

The fourth row of the 'Cumulative \%' shows the cumulated variance of the four factors $(64.219 \%)$ which were developed by the Kaiser-criteria. It is above the necessary $60 \%$.

The 5-factor solution would have been reasonable regarding the methods but relying on the fulfilled factor analysis there would only be one variable in the factor 5 . Therefore, we used a 4-factor solution which means that we replaced 27 variables. It explains with $100 \%$ with 4 factors which explains in $64.22 \%$. After this, we rotated the factors during their selection to filter the correlated factors without relation and also in order to get a more simple and understandable solution. We used the Varimax rotational method during which the orthogonal rotation results in correlating factors.

Finally, we reached a 4-factor solution as a result of the analysis, where the $\mathrm{KMO}=0.886$ and the explained variance is $64.22 \%$. The names of the factors are the following:

- FACTOR1: Quality of the service

- FACTOR2: Efficiency of the system

- FACTOR3: Quality of the online material

- FACTOR4: Usability of the system

We used logistic regression for the results of the factor analysis. Our aim was to determine the importance of a given factor for the users of the CUB and the FEB. The dependent variable is the factor CUB and the independent variable is the factor of FEB. Table 5 and 6 represent the first phase of the analysis. Table 4 shows the constant Wald-statistic in the pre-analysis phase, which is the square of the beta (B) and the standard error. It demonstrated that there is not a significance.

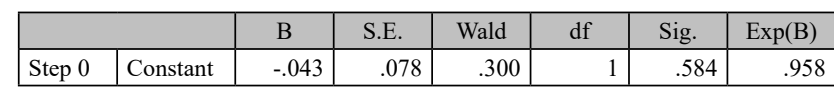

Table 5: Parameter estimation based on the Wald-statistic (source: own calculation)

Table 5 represents the individual effect of the independent variables yet not used in the analysis, according to which FACTOR1. FACTOR2 and FACTOR3 are also significant on their own, while the forth variable is not. The second part of the analysis demonstrates the final result. We used the „Enter” method, which means that we used the four independent variables in the analysis at same time. 


\begin{tabular}{|l|c|c|c|c|c|}
\hline \multicolumn{2}{|c|}{} & Score & df & Sig. \\
\hline \multirow{4}{*}{ Step 0 } & Variables & FACTOR1 & 49.687 & 1 & .000 \\
\cline { 3 - 6 } & & FACTOR2 & 20.899 & 1 & .000 \\
\cline { 3 - 6 } & FACTOR3 & 22.418 & 1 & .000 \\
\cline { 3 - 6 } & & FACTOR4 & .401 & 1 & .526 \\
\cline { 2 - 6 } & & & 97.189 & 4 & .000 \\
\hline
\end{tabular}

Table 6. Significance of individual effects of variables (source: own calculation)

Table 7 also applies the Wald-statistic. If the given variable is significant, then it supports the model. It is obvious that FACTOR1. FACTOR2 and FACTOR3 contributes to the model, while FACTOR4 does not. The $\operatorname{Exp}(\mathrm{B})$ indicates how each variables correct the estimation.

\begin{tabular}{|c|c|c|c|c|c|c|c|c|c|}
\hline & \multirow[t]{2}{*}{ B } & \multirow{2}{*}{ S.E. } & \multirow{2}{*}{ Wald } & \multirow{2}{*}{ df } & \multirow{2}{*}{ Sig. } & \multirow{2}{*}{$\operatorname{Exp}(B)$} & \multicolumn{2}{|c|}{$\begin{array}{c}95.0 \% \text { C.I.for } \\
\operatorname{EXP(B)}\end{array}$} \\
\hline & & & & & & & & Lower & Upper \\
\hline \multirow{5}{*}{ Step 1(a) } & FACTOR1 & .759 & .105 & 52.118 & 1 & .000 & 2.135 & 1.738 & 2.624 \\
\hline & FACTOR2 & .521 & .102 & 26.021 & 1 & .000 & 1.683 & 1.378 & 2.056 \\
\hline & FACTOR3 & -.596 & .104 & 32.805 & 1 & .000 & .551 & .449 & .676 \\
\hline & FACTOR4 & -.115 & .087 & 1.748 & 1 & .186 & .891 & .751 & 1.057 \\
\hline & Constant & -.108 & .087 & 1.549 & 1 & .213 & .898 & & \\
\hline
\end{tabular}

Table 7: Wald-statistic (source: own calculation)

Regarding this, FACTOR1 corrects the estimation the most $(\operatorname{Exp}(B)=2.135)$ with $113.5 \%$, while FACTOR 2 corrects it with $68.3 \%$. FACTOR3 worsens the estimation with $44.9 \%$, which means that according to the CUB users the first factor is twice, while the second factor is 1.683 times more important than according to the FEB.

\section{Discussion}

In our study we used the ELSS model (Wang, Wang and Shee, 2007) based on IS success model developed by DeLone and McLean (2003). We used it at both institutions. Our results of the questionnaire evaluation are the same as the main line of article by Halonen et al (2009).

System quality has a significant influence on use and user satisfaction (DeLone and McLean, 2003). In our research the system was Moodle platform and when evaluating 'System Quality' we considered Moodle's functionality and the technical support that was connected with its use.

Respondents perceived that the e-learning system operated almost without reproaches and we interpret that it describes the stability and good availability of the system.

Information quality has a significant impact on use and user satisfaction (DeLone and McLean, 2003). Information is an important factor in the e-learning system. The respondents were mainly satisfied with the organized information. The replies did not indicate if the organization of information helped the students perceive the structure of the degree.

Replies concerning 'Information Quality' highlighted three issues on 'Service Quality'. The students perceived that the plans of study blocks helped them understand the purpose of their studies. Another important information concerned students' experiment on receiving essential and needed information for their degree from the e-learning system. The third significant success factor was the instructions on giving evidence of expertise (Halonen et al, 2009).

Service quality builds on all support that is offered to its users (DeLone and McLean, 2003). In our study we measured 'Service Quality' by evaluating interaction between the students and teachers. The students replied that they were mostly satisfied with interaction. The students had received support and guidance and their questions were answered. These results tell us that the respondents were satisfied with given guidance.
Service quality is extremely important because due to bad service customers may be lost (DeLone and McLean, 2003). From the e-learning approach we could interpret that weak interaction in the e-learning system could lead to reluctance to study. Our measures showed that 'service quality' was good.

Benefits in e-learning are positive consequences and in our research they were positive consequences for studies and evidences of experience. The most important output was that the students perceived to benefit from the e-learning system when they accomplished their degrees (Halonen et al, 2009). Benefits indicated that the e-learning system supports students when they accomplish their degrees.

\section{Conclusion}

We used statistic methods to examine the quality evaluation of the e-Learning usage among the students and the lecturers of the FEB and the CUB. We found significant differences between the CUB's and the FEB's application as well as between the students' and the lecturers' evaluation by performing a t-test. We determined relying on the result, that it is more effective and better to operate the e-Learning system under organized circumstances. This confirmed our hypothesis. We have created 4 factors from the 27 variables by factor analysis and we performed logistic regression on them. Our result shows according to the CUB users the quality of the service is more than twice as good according to the FEB users. While the efficiency of the system is 1.683 times more important. This method can be used to evaluate (compare) the quality of e-Learning services among educational institutes.

\section{References}

Balogh, P., Bai, A., Popp, J., Huzsvai, L. and Jobbágy, P. (2015) 'Internet-orientated Hungarian car drivers' knowledge and attitudes towards biofuels' Renewable and Sustainable Energy Reviews, Vol 48. pp. 17-26. http://dx.doi.org/10.1016/j. rser.2015.03.045

Bocarnea, M. C., Reynolds, R. A. and Baker, J. D. (2012) Online instruments. data collection. and electronic measurements: Organizational advancements, United States: IGI Global. http:// dx.doi.org/10.4018/978-1-4666-2172-5

DeLone, W. H. and McLean, E. R. (1992) 'Information System Success: The Quest for The Dependent Variable' Information Systems Research Vol 3. No 1., pp 60-95. http://dx.doi. org/10.1287/isre.3.1.60

DeLone, W. H. and McLean, E. R. (2003) 'The DeLone and McLean model of information systems success: a ten-year update' Journal of Management Information Systems. Vol 19. No 4., pp. 9-30.

Eom, S. B., Ashill, N. J., Arbaugh, J. B., and Stapleton, J. L. (2012) 'The Role of Information Technology in ELearning Systems Success' Human Systems Management. Vol 31. No 3-4., pp 147-163. http://dx.doi.org/10.3233/HSM-2012-0767

Eom, S. (2015) 'Effects of self-efficacy and self-regulated learning on LMS user satisfaction and LMS effectiveness' $.21 \mathrm{st}$ Americas Conference on Information Systems. AMCIS 2015; El Conquistador Resort and Convention CenterFajardo; Puerto Rico

Field, A.P. (2009) Discovering statistics using SPSS: (and sex. drugs and rock'n'roll). 3rd ed. Los Angeles: SAGE Publications Gal, T., Nagy, L., David, L., Vasa, L and Balogh, P. (2013) 'Technology planning system as a decision support tool for dairy farms in Hungary“ Acta Polytechnica Hungarica. Vol 10. No 8., pp. 231-244.

Halonen R., Acton T., Golden W. and Conboy K. (2009) 
'Delone\&McLean success model as a descriptive tool in evaluating a virtual learning environment" The Whitaker Institute for Innovation and Societal Change, International Conference on Organizational Learning, Knowledge and Capabilities (OLKC 2009), Amsterdam, the Netherlands

Karima, A. and Mostafa, A. (2016) 'Improvement of the quality of development process of E-learning and M-learning systems' International Journal of Applied Engineering Research. Vol 11. No 4. pp. 2474-2477.

Lengyel, P., Füzesi, I., Péntek, Á. and Herdon, M. (2016) 'Human resource development using e-learning for Hungarian agricultural experts' Journal of Agricultural Informatics. Vol 7. No 1., pp. 94-102. http://dx.doi.org/10.17700/jai.2016.7.1.262 Lengyel,P.andHerdon,M.(2012) ‘e-Learningminőségfejlesztése a Debreceni Egyetem Agrár- és Gazdálkodástudományok Centrumában“ (e-Learning Quality Development of the University of Debrecen. Centre of Agricultural and Applied Economic Sciences) Információs Társadalomtudományi Folyóirat Vol 12. No 3., pp. 49-59.

Li, Y., Fu, Z. and Duan, Y. (2013) 'Evaluating system quality of e-learning programs: A study based on factor analysis ${ }^{\circ}$ Sensor Letters. Vol 11. No 6-7., pp. 1180-1184. http://dx.doi. org/10.1166/s1.2013.2863

Sajtos, L. and Mitev, A. (2007) SPSS Kutatási és Adatelemzési Kézikönyv (SPSS Research and Data Analysis Manual). Budapest: Alinea Kiadó

Silambannan, R. and Srinath, M. V. (2013) 'A convictive framework for quality base construction and evaluation of e-learning website' Journal of Theoretical and Applied Information Technology. Vol 58. No 1., pp. 147-156.

Szakály, Z., Balogh. P., Jasák, H., Szabó, S. and Szente, V. (2014) 'The Influence of Personal Values on the Transition towards Health-conscious Diet: a Segmentation Approach.' Journal Of Food And Nutrition Research. Vol 2. No 8., pp. 476-484. http:// dx.doi.org/10.12691/jfnr-2-8-8

Szilágyi, R. (2012) 'New information and communication technologies in agriculture - factors. drivers and application possibilities“. Journal of Agricultural Informatics. Vol 3., No 1., pp. 10-18. http://dx.doi.org/10.17700/jai.2012.3.1.77

Várallyai, L., Botos, Sz. and Péntek, A. (2015) 'Socioeconomic Factors of Soil Pollution' Procedia Economics and Finance. Vol 33. pp. 573-583. http://dx.doi.org/10.1016/S22125671(15)01739-6

Wang, Y. S., Wang, H. Y. and Shee, D. Y. (2007) 'Measuring e-Learning success in an organizational context: Scale development and validation ' Computers in Human Behavior. Vol 23., pp. 1792-1808. http://dx.doi.org/10.1016/j.chb.2005.10.006

\section{Appendix 1.}

\section{Questionnaire}

System Quality (questions 1-7)

1. The LMS provides high availability.

2. The LMS is easy to use.

3. The LMS is user friendly.

4. The LMS provides interactive features between users and system.

5. The LMS provides personalized information presentation.

6. The LMS provides charming feature to attract users.

7. The LMS provides high speed of accessing information.

\section{Information Quality (questions 8-13)}

8. The LMS provides information that is exactly what you need. 9. The LMS provides information you need in time.

10. The LMS provides information that is relevant to your job.

11. The LMS provides sufficient information.

1. The LMS provides up-to-date information.

Service Quality (questions 14-18)

13. The LMS provides proper level of on-line assistance and explanation.

14. The LMS developers interact with users extensively during the development of e-learning system.

15. The IS department staff provide high availability for consultation.

16. The IS department responds to your suggestion for future enhancements of e-learning system cooperatively.

17. The IS department provides satisfactory support to users using e-learning system.

Benefits (questions 18-24)

18. The LMS helps you improve your job performance.

19. The LMS helps the organization enhance competitiveness or create strategic advantage.

20. The LMS enables the organization to respond more quickly to change.

21. The LMS helps the organization provide better products or services to customers.

22. The LMS helps the organization save cost.

23. The LMS helps the organization to speed up transactions or shorten product cycles.

24. The LMS helps the organization increase return on financial assets.

Conclusion (questions 25-27)

25. As a whole, the performance of the e-learning system is good.

26. As a whole, the e-learning system is successful.

27. You are satisfied with the e-learning system. 
Appendix 2.

Descriptive statistics on teachers' answers

\begin{tabular}{|c|c|c|c|c|c|}
\hline $\begin{array}{l}\text { question } \\
\text { number }\end{array}$ & Institution & $\mathrm{N}$ & Mean & $\begin{array}{c}\text { Std. } \\
\text { Deviation }\end{array}$ & $\begin{array}{c}\text { Std. Error } \\
\text { Mean }\end{array}$ \\
\hline \multirow{2}{*}{1.} & FEB & 46 & 9.391 & 0.8814 & 0.1300 \\
\hline & CUB & 50 & 9.400 & 0.6999 & 0.0990 \\
\hline \multirow{2}{*}{2.} & FEB & 46 & 8.826 & 0.9263 & 0.1366 \\
\hline & CUB & 50 & 8.080 & 1.2262 & 0.1734 \\
\hline \multirow{2}{*}{3.} & FEB & 46 & 8.174 & 1.1016 & 0.1624 \\
\hline & CUB & 50 & 8.100 & 1.3740 & 0.1943 \\
\hline \multirow{2}{*}{4.} & FEB & 46 & 7.261 & 2.3705 & 0.3495 \\
\hline & CUB & 50 & 8.020 & 1.7437 & 0.2466 \\
\hline \multirow{2}{*}{5.} & FEB & 46 & 7.609 & 3.1516 & 0.4647 \\
\hline & CUB & 50 & 7.820 & 1.6123 & 0.2280 \\
\hline \multirow{2}{*}{6.} & FEB & 46 & 7.304 & 3.4825 & 0.5135 \\
\hline & CUB & 50 & 7.620 & 1.7010 & 0.2406 \\
\hline \multirow{2}{*}{7.} & FEB & 46 & 6.478 & 2.5625 & 0.3778 \\
\hline & CUB & 50 & 8.520 & 1.2493 & 0.1767 \\
\hline \multirow{2}{*}{8.} & FEB & 46 & 9.261 & 0.9985 & 0.1472 \\
\hline & CUB & 50 & 9.120 & 1.2720 & 0.1799 \\
\hline \multirow{2}{*}{9.} & FEB & 46 & 8.652 & 2.1418 & 0.3158 \\
\hline & CUB & 50 & 9.360 & 0.6928 & 0.0980 \\
\hline \multirow{2}{*}{10.} & FEB & 46 & 9.609 & 0.7142 & 0.1053 \\
\hline & CUB & 50 & 9.660 & 0.4785 & 0.0677 \\
\hline \multirow{2}{*}{11.} & FEB & 46 & 8.565 & 1.6553 & 0.2441 \\
\hline & CUB & 50 & 8.940 & 1.1141 & 0.1576 \\
\hline \multirow{2}{*}{12.} & FEB & 46 & 9.043 & 1.4446 & 0.2130 \\
\hline & CUB & 50 & 9.420 & 0.5746 & 0.0813 \\
\hline \multirow{2}{*}{13.} & FEB & 46 & 8.000 & 2.3851 & 0.3517 \\
\hline & CUB & 50 & 8.940 & 0.8184 & 0.1157 \\
\hline \multirow{2}{*}{14.} & FEB & 46 & 7.913 & 1.7362 & 0.2560 \\
\hline & CUB & 50 & 9.100 & 0.6776 & 0.0958 \\
\hline \multirow{2}{*}{15.} & FEB & 46 & 8.696 & 1.5036 & 0.2217 \\
\hline & CUB & 50 & 9.520 & 0.6773 & 0.0958 \\
\hline \multirow{2}{*}{16.} & FEB & 46 & 8.435 & 1.4855 & 0.2190 \\
\hline & CUB & 50 & 9.380 & 0.7253 & 0.1026 \\
\hline \multirow{2}{*}{17.} & FEB & 46 & 8.261 & 2.1953 & 0.3237 \\
\hline & CUB & 50 & 9.540 & 0.6131 & 0.0867 \\
\hline \multirow{2}{*}{18.} & FEB & 46 & 5.261 & 3.4797 & 0.5131 \\
\hline & CUB & 50 & 5.860 & 2.1666 & 0.3064 \\
\hline \multirow{2}{*}{19.} & FEB & 46 & 7.522 & 3.4237 & 0.5048 \\
\hline & CUB & 50 & 8.160 & 1.5167 & 0.2145 \\
\hline 20 & FEB & 46 & 7.304 & 3.2446 & 0.4784 \\
\hline 20. & CUB & 50 & 7.740 & 1.9878 & 0.2811 \\
\hline 21 & FEB & 46 & 8.174 & 2.8387 & 0.4185 \\
\hline 21. & CUB & 50 & 8.860 & 1.4429 & 0.2041 \\
\hline 22 & FEB & 46 & 7.783 & 2.8590 & 0.4215 \\
\hline 22. & CUB & 50 & 7.800 & 2.1381 & 0.3024 \\
\hline 23 & FEB & 46 & 5.478 & 2.9645 & 0.4371 \\
\hline 25. & CUB & 50 & 6.080 & 3.0226 & 0.4275 \\
\hline 24 & FEB & 46 & 6.913 & 3.5890 & 0.5292 \\
\hline 24. & CUB & 50 & 6.740 & 2.4974 & 0.3532 \\
\hline 25 & FEB & 46 & 9.609 & 0.7142 & 0.1053 \\
\hline 25. & CUB & 50 & 9.320 & 1.3915 & 0.1968 \\
\hline 26 & FEB & 46 & 9.043 & 0.8681 & 0.1280 \\
\hline 20. & CUB & 50 & 8.380 & 1.2919 & 0.1827 \\
\hline 27 & FEB & 46 & 8.652 & 0.7664 & 0.1130 \\
\hline 21. & CUB & 50 & 8.540 & 1.0539 & 0.1490 \\
\hline
\end{tabular}

\section{Descriptive statistics on students' answers}

\begin{tabular}{|c|c|c|c|c|c|}
\hline $\begin{array}{l}\text { question } \\
\text { number }\end{array}$ & Institution & $\mathrm{N}$ & Mean & $\begin{array}{c}\text { Std. } \\
\text { Deviation }\end{array}$ & $\begin{array}{l}\text { Std. Error } \\
\text { Mean }\end{array}$ \\
\hline \multirow{2}{*}{1.} & FEB & 288 & 8.635 & 1.0030 & 0.0591 \\
\hline & CUB & 273 & 8.418 & 1.6938 & 0.1025 \\
\hline \multirow{2}{*}{2.} & FEB & 288 & 7.844 & 1.8020 & 0.1062 \\
\hline & CUB & 273 & 8.110 & 1.6701 & 0.1011 \\
\hline \multirow{2}{*}{3.} & FEB & 288 & 7.792 & 1.1739 & 0.0692 \\
\hline & CUB & 273 & 8.132 & 1.6079 & 0.0973 \\
\hline \multirow{2}{*}{4.} & FEB & 288 & 6.667 & 1.4435 & 0.0851 \\
\hline & CUB & 273 & 7.253 & 1.6106 & 0.0975 \\
\hline \multirow{2}{*}{5.} & FEB & 288 & 6.854 & 2.0498 & 0.1208 \\
\hline & CUB & 273 & 7.418 & 1.9254 & 0.1165 \\
\hline \multirow{2}{*}{6.} & FEB & 288 & 6.000 & 2.2585 & 0.1331 \\
\hline & CUB & 273 & 6.681 & 2.0030 & 0.1212 \\
\hline \multirow{2}{*}{7.} & FEB & 288 & 8.115 & 1.2258 & 0.0722 \\
\hline & CUB & 273 & 8.088 & 1.7677 & 0.1070 \\
\hline \multirow{2}{*}{8.} & FEB & 288 & 7.677 & 1.3447 & 0.0792 \\
\hline & CUB & 273 & 7.923 & 1.7525 & 0.1061 \\
\hline \multirow{2}{*}{9.} & FEB & 288 & 6.813 & 1.8364 & 0.1082 \\
\hline & CUB & 273 & 6.989 & 2.1343 & 0.1292 \\
\hline \multirow{2}{*}{10.} & FEB & 288 & 8.656 & 0.9239 & 0.0544 \\
\hline & CUB & 270 & 8.078 & 1.7043 & 0.1037 \\
\hline \multirow{2}{*}{11.} & FEB & 288 & 7.552 & 1.4009 & 0.0825 \\
\hline & CUB & 273 & 7.374 & 1.6448 & 0.0995 \\
\hline \multirow{2}{*}{12.} & FEB & 288 & 7.583 & 1.5483 & 0.0912 \\
\hline & CUB & 273 & 7.659 & 1.7334 & 0.1049 \\
\hline \multirow{2}{*}{13.} & FEB & 288 & 8.010 & 1.5806 & 0.0931 \\
\hline & CUB & 270 & 7.611 & 1.8635 & 0.1134 \\
\hline \multirow{2}{*}{14.} & FEB & 288 & 6.417 & 2.5851 & 0.1523 \\
\hline & CUB & 270 & 7.100 & 2.0535 & 0.1250 \\
\hline \multirow{2}{*}{15.} & FEB & 288 & 5.875 & 2.5220 & 0.1486 \\
\hline & CUB & 270 & 7.289 & 1.9883 & 0.1210 \\
\hline \multirow{2}{*}{16.} & FEB & 288 & 5.885 & 2.1778 & 0.1283 \\
\hline & CUB & 270 & 7.433 & 2.0316 & 0.1236 \\
\hline \multirow{2}{*}{17.} & FEB & 288 & 6.542 & 2.2302 & 0.1314 \\
\hline & CUB & 270 & 7.511 & 2.0761 & 0.1263 \\
\hline \multirow{2}{*}{18.} & FEB & 288 & 6.510 & 2.4237 & 0.1428 \\
\hline & CUB & 273 & 7.659 & 1.8504 & 0.1120 \\
\hline \multirow{2}{*}{19.} & FEB & 288 & 7.510 & 2.3314 & 0.1374 \\
\hline & CUB & 273 & 7.956 & 1.9246 & 0.1165 \\
\hline 20 & FEB & 288 & 7.396 & 2.1518 & 0.1268 \\
\hline 20 & CUB & 273 & 7.868 & 2.0963 & 0.1269 \\
\hline 21 & FEB & 288 & 7.177 & 2.3134 & 0.1363 \\
\hline 21. & CUB & 273 & 8.143 & 1.6510 & 0.0999 \\
\hline 22 & FEB & 288 & 6.781 & 2.9033 & 0.1711 \\
\hline 22. & CUB & 273 & 8.363 & 1.8402 & 0.1114 \\
\hline 23 & FEB & 288 & 6.833 & 2.5113 & 0.1480 \\
\hline 25. & CUB & 273 & 7.802 & 1.9547 & 0.1183 \\
\hline 24 & FEB & 288 & 7.073 & 2.0511 & 0.1209 \\
\hline 24. & CUB & 273 & 8.319 & 1.6194 & 0.0980 \\
\hline 25 & FEB & 288 & 8.979 & 1.0119 & 0.0596 \\
\hline 25. & CUB & 273 & 8.879 & 1.5134 & 0.0916 \\
\hline & FEB & 288 & 7.375 & 1.5455 & 0.0911 \\
\hline 26. & CUB & 273 & 8.286 & 1.6221 & 0.0982 \\
\hline & FEB & 288 & 7.771 & 1.2890 & 0.0760 \\
\hline 27. & CUB & 273 & 8.187 & 1.7941 & 0.1086 \\
\hline
\end{tabular}

